Combinatory Linguistics 



\section{Combinatory Linguistics}

by

Cem Bozşahin

De Gruyter Mouton 
ISBN 978-3-11-025170-8

e-ISBN 978-3-11-029687-7

Library of Congress Cataloging-in-Publication Data

A CIP catalog record for this book has been applied for at the Library of Congress.

Bibliographic information published by the Deutsche Nationalbibliothek

The Deutsche Nationalbibliothek lists this publication in the Deutsche Nationalbibliografie; detailed bibliographic data are available in the Internet at http://dnb.dnb.de.

(C) 2012 Walter de Gruyter GmbH, Berlin/Boston

Printing: Hubert \& Co. GmbH \& Co. KG, Göttingen

(2) Printed on acid-free paper

Printed in Germany

www.degruyter.com 
in memory of:

Doğan Bozşahin

Ferhunde Bozşahin

Saliha İdemen

Ferruh İdemen 
